Article

\title{
Field Archaeologists as Eyewitnesses to Site Looting
}

\author{
Blythe Alison Bowman Balestrieri \\ L. Douglas Wilder School of Government \& Public Affairs, Virginia Commonwealth University, \\ 1001 West Franklin St \#2013, Richmond, VA 23284, USA; bbalestrieri@vcu.edu; Tel.: +1-804-828-5708
}

Received: 8 May 2018; Accepted: 29 August 2018; Published: 6 September 2018

check for updates

\begin{abstract}
In a recent worldwide study on the nature, scope, and frequency of archaeological site looting, the vast majority of field archaeologists reported having had multiple encounters with archaeological site looters both on- and off-site. Despite the criminalization of looting in most countries' domestic statutory schemes, nearly half of surveyed field archaeologists do not report looting activity to external law enforcement or archaeological authorities when they encounter it. The rationales for their actions-or inactions-are examined within a criminological framework, and field archaeologists' perspectives on looters as "criminals" and "victims" are explored. The paper concludes with a consideration that the criminalization of looting creates an emergent duty to report among archaeologists, and how they choose to address site looting changes their role in and relationship to the trade in illicitly obtained antiquities.
\end{abstract}

Keywords: archaeological site looting; archaeological ethics; criminalization

\section{Introduction}

Despite the existence of various national and international regulatory efforts, the global antiquities market continues to be largely fed by illicit digging at archaeological sites around the world. "Looting" is conventionally defined as the illegal removal of culturally significant material from archaeological sites for commercial gain, the act of which destroys archaeological context or evidence needed to learn from the site (Bowman Proulx 2013), and is largely criminalized by many if not most countries. Archaeological site looting typically occurs when culturally significant objects in developing, archaeologically rich "source" countries are removed without permission and subsequently sold and collected in developed, acquisitive, "demand" countries (Bowman Proulx 2013; Brodie 2011). As Gill and Chippindale (1993) have argued, damage to the archaeological landscape has both intellectual and material consequences. That is, when archaeological knowledge is lost to looting, so is an important source of cultural information, national identity, historical memory, and even economy. Looting destroys both the tangible and intangible elements of cultural heritage.

Looting has only relatively recently piqued the interest of criminologists, for whom the topic is typically subsumed under the broader rubric of "art crime" (Bowman Proulx 2011), ${ }^{1}$ and there is a growing body of criminological research on looting and its interfacing with the trade in illicitly obtained art as well as other transnational illicit markets. ${ }^{2}$ Specifically, site looting is often conflated

Cf., for example, (Tijhuis 2006; Massy 2001; Aarons 2001; Aarons et al. 1998; Bernick 1998; Conklin 1994).

The earliest comprehensive criminological treatment of looting and antiquities can be traced to the work of criminologists Polk \& Alder who were among the first to examine the trade specifically as a transnational criminal market. See (Alder and Polk 2002, 2005). For example, Simon Mackenzie's 2005 doctoral dissertation was the first scholarly application of white collar criminology to examine the "demand" end of archaeological site looting; Edgar Tijhuis (2006) investigated the licit-illicit interfacing of looted antiquities and the antiquities trade through a transnational criminological lens; Bowman Proulx (2010) situated her analysis of archaeological site looting within an organized criminal framework. These are but three examples of the scholarly treatment of looting within the specific context of criminology, all of which helped to establish the scholarly foundations upon which much current work has drawn and expanded. 
with art theft, the latter of which tends to focus on high-value thefts from museums, galleries, or private property (Tijhuis 2006). This scholarly commingling of art theft with looting is nonetheless problematic in that, upon closer examination, one has very little in common with the other. Art theft, for example, typically involves the stealing of an identifiable object owned by someone; looted antiquities, on the other hand, are never-before-seen objects recovered through clandestine digging, meaning that when they appear on the art market, they cannot be recognized and legally construed as stolen (Brodie 2006). After all, as Gill and Chippindale (1993, p. 623) have observed, "Who can report a Cycladic figure as stolen when it has been lying unseen in a grave for more than four thousand years?". In fact, the only commonality among art thefts and the looting of archaeological sites is that both activities involve illegally removed objects to which some sort of intangible value and significance have been attached. This impalpable value of art and antiquities is socially constructed, meaning an object's value is whatever a particular beholder assigns to it, whether it be commercial, aesthetic, or artistic in nature. Beyond this common denominator of subjective value attribution, however, art theft and site looting are conceptually distinct, and it is only relatively recently that criminologists have begun to examine each phenomenon on its own terms.

This emergent scholarly interest in site looting has caused criminologists to take an unprecedented dive into the world of archaeological scholarship, resulting in a hyper-specialized-if not altogether boutique-research niche under which a growing number of criminologists can be subsumed (cf., for example, Balcells Magrans 2018; Mackenzie and Davis 2014; Brisman 2011). In turn, archaeologists have similarly begun to avail themselves of criminological concepts and terminology, drawing new attention to the looting of antiquities from a diversified audience. Today, the intersection of archaeology with criminology raises fewer questioning eyebrows among scholars, and there are even archaeologists based in their university's departments of criminology.

While the intersection of archaeology with criminology has yielded useful scholarship, ${ }^{3}$ a number of problematic trends have emerged. That is, the examination of looting as criminal activity brings with it panoply of socio-legal implications that, at one time or another, a number of scholars-admittedly including this author-have overlooked. Specifically, I argue that the widespread criminalization of archaeological site looting-as well as archaeologists' application of criminological terminology-e.g., crime, criminal, criminality, criminogenic, criminological, criminalize, stealing, theft, and so forth-changes not only the narrative framework surrounding looting but the field archaeologist's obligations upon bearing witness to it. In other words, if looting is a crime encountered not infrequently by archaeologists in the field, then it becomes incumbent upon field archaeologists as eyewitnesses to criminal activity to think of and respond to it differently.

This paper begins with a presentation of findings from a study focused on surveyed field archaeologists' personal encounters with archaeological looting. The actions that archaeologists report having taken after having borne witness to it are discussed, as well as archaeologists' reported justifications for those actions. The rationales for their actions-or inactions—in response to looting are examined within a criminological framework, and the dichotomy of looters as either "criminals" or "victims" is explored. The paper concludes with a consideration that criminalized archaeological site looting produces an emergent duty to report among archaeologists, and that how they choose to respond to such a crime changes their role in and relationship to the trade in illicitly obtained antiquities. ${ }^{4}$

3 For example, Simon Mackenzie's 2005 doctoral dissertation was the first scholarly application of white collar criminology to examine the "demand" end of archaeological site looting; Edgar Tijhuis (2006) investigated the licit-illicit interfacing of looted antiquities and the antiquities trade through a transnational criminological lens; Bowman Proulx (2010) situated her analysis of archaeological site looting within an organized criminal framework. These are but three examples of the scholarly treatment of looting within the specific context of criminology, all of which helped to establish the scholarly foundations upon which much current work has drawn and expanded.

4 Provenance refers to the documented ownership history of an object. The term is frequently used in the art community to refer, in other words, to what has happened to an antiquity since it came out of the ground. Among archaeologists, on the other hand, provenience refers not to past ownership history but information regarding the original findspot of the object (Coggins 1969, 1998); where and how, in other words, the antiquity came out of the ground. 


\section{Field Archaeologists' Reported Experiences with Site Looting}

Given the relevance of fieldwork to the practice and disciplinary identity of archaeology ${ }^{5}$ (Holtorf 2005), which necessarily puts archaeologists in close proximity to the phenomenon of site looting, field archaeologists' personal assessments of and experiences with looting are a valuable source of information. Whether the agenda in the field is excavation, survey, post-excavation analysis, conservation, or site management, field archaeologists are "on the ground," working on the very sites of interest to looters, and therefore highly likely to experience site looting at some point and in some capacity during their field careers. Field archaeologists are very much akin to "eyewitnesses" in that they are often the first professionals to encounter never-before-seen site looting-or even looting activity in progress-simply by virtue of where they work. Their firsthand experiences with, opinions about, and responses to local site looting represent vital frontline perspectives on a global issue (Bowman Proulx 2013).

Moreover, given the significance of fieldwork to the practice of archaeology, archaeologists' experiences with and thoughts about looting are even more salient in that they represent but one group of stakeholders with deeply vested interests in the matter. The practice and disciplinary identity of archaeology, in fact, very much depend on the fate of the archaeological record, in which site looting plays a direct and significant part. When objects are illicitly removed from the ground and shipped off for sale, never before having been seen-let alone studied-the relationship of those objects to their archaeological context and the information about the human past derived from it are irretrievably lost. Archaeological interpretations of the past necessarily depend on the physical remains of human behavior, and the context in which antiquities and other objects of cultural significance are found is key in reconstructing the past. ${ }^{6}$ For the livelihood of archaeological scholarship, then, the archaeological record is central, and fieldwork is the central means by which to access it.

When field archaeologists do encounter looting, how do they decide what specific action-or inaction — to take in response? What responsibility, if any, belongs to field archaeologists in curbing looting activity? On the "demand" end of the trade in unprovenanced antiquities, the dramatis personae of criminological interest have been the collectors, dealers, auction houses, and museums; on the "source" end of things, some studies have examined the organization of looting and trafficking networks. ${ }^{7}$ Studies on the specific role of archaeologists in the illicit antiquities trade are limited ${ }^{8}$ and few, if any, have focused exclusively on the experience of field archaeologists who have firsthand encounters with looting. ${ }^{9}$ With vested interests both personal and professional firmly entrenched in the intellectual value of archaeological resources, field archaeologists' interactions with and responses to illicit digging and site destruction warrant closer scrutiny.

5 Moser (2007) writes that archaeological fieldwork is not only a "rite of passage that individuals must pass to gain admission to the professional community, but also as a cultural locus of experience that serves to forge their [archaeologists'] identity" (p. 243). In fact, archaeologists who have not or do not participate in fieldwork are often characterized as 'armchair archaeologists' (Flannery and Marcus 1998, p. 36) - a not-so-flattering nickname that conjures the image of a "dilettante who spins fine theories from inadequate facts and never rolls up his sleeves to do any fieldwork himself" (Summers 1950, p. 101). It is hardly surprising, then, that fieldwork lies at the core of archaeology's disciplinary identity as well as its scientific authenticity from both inside and out (Holtorf 2005; DeBoer 1999).

6 Context yields information not only about where an object is found, but also on how it came to be there, and what has subsequently happened to it (Fagan 1985). An archaeological site is a complex web of relationships, the meanings of which are more than the sum of their parts (Brodie 2002), and thus looted antiquities are "cultural orphans which, torn from their contexts, remain forever dumb and virtually useless for scholarly purposes" (Cannon-Brookes 1994, p. 350). For archaeologists, both an object and its context are equally important; in other words, "'it is not what you find but how you find it"' (Taylor 1948, p. 154).

7 Cf., for example, Mackenzie and Davis (2014); Balcells Magrans (2018).

8 Cf., for example, (Brodie 2011).

9 Cf. (Bowman Proulx 2011). 
In an extensive recent study ${ }^{10}$ on the global scope, nature, and frequency of archaeological site looting, from which select data are presented here, Bowman Proulx (2013) invited nearly 15,000 archaeologists working throughout the world to participate in surveys and interviews about their experiences with and opinions about site looting. This paper presents qualitative data derived from this study, which were analyzed by means of an emergent approach. With a robust response rate of $16 \%(N=2358), 59.1 \%$ of the sample population were male, $27.9 \%$ between the ages of 31 and $40 ; 91.7 \%$ held at least a master's degree, and 82.6\% spoke English as their first language. In total, $29.9 \%$ of the respondents indicated that they had been active in archaeological fieldwork since the 1990s, with archaeological site excavation as the most commonly reported type of fieldwork experience $(81.8 \%)$. Nearly three-quarters of the 2358 respondents $(70 \%)$ indicated that they had participated in 10 or more archaeological projects in their careers to date, and a total of 118 countries were reported among respondents as the primary location of the majority of their archaeological fieldwork experience. The typical survey respondent was an English-speaking male with both higher education and professional training in archaeology and/or related disciplines, with anywhere between 10 and 20 years of fieldwork experience, primarily on archaeological site excavation (Bowman Proulx 2011, 2013). Participants' feedback is presented below accompanied by their random, computer-generated identification numbers and their reported location of the majority of their archaeological fieldwork experience.

\section{Archaeologists' Reported Eyewitness Encounters with Looting}

Nearly $80 \%(N=1662)$ of respondents reported having witnessed firsthand looting or evidence of looting ${ }^{11}$ while participating in fieldwork of any kind. As reflected in Figure 1 below, this reported looting is a globally pervasive phenomenon, not limited to one aggregate geographic region ${ }^{12}$ or another:

10 See (Bowman Proulx 2013). In total, 2358 online surveys were completed which provided quantitative data for regression analysis, and the survey's open-ended questions as well as follow-up interviews yielded an additional 3009 pieces of qualitative feedback for emergent analysis.

11 Typically, this is evidence of unauthorized digging, which can be in the form of trenches, holes, pits, and the haphazard scattering of artifacts which are clearly not part of systematic, authorized excavation. Other reported evidence includes "sieve screens set up at a site where no archaeological teams [are] working"; "stashes of hidden looted artifacts near the site"; human burials disinterred; collapsed walls or other architectural features; broken pottery, empty beer cans, cigarette butts, foot wrappers, and other miscellaneous trash (Bowman Proulx 2013).

12 These standard geographic regions are established in the CIA World Factbook as such: North America = Canada, United States, Mexico; Central American \& Caribbean = Antigua, Barbados, Belize, Costa Rica, Dominican Republic, El Salvador, Guatemala, Honduras, Netherlands Antilles, Panama, Puerto Rico, Turks \& Caicos; South America = Argentina, Bolivia Brazil, Chile, Colombia, Ecuador, Peru; Western, Central Europe, \& United Kingdom = Austria, Belgium, Czech Republic, Denmark, Finland, France, Germany, Hungary, Iceland, Ireland, Italy, Norway, Poland, Portugal, Scotland, Spain, Sweden, Switzerland, Malta, Netherlands, United Kingdom; Eastern, Southeastern Europe, \& Eurasia = Albania, Croatia, Bulgaria, Armenia, Georgia, Greece, Lithuania, Macedonia, Romania, Russia, Serbia, Slovakia, Slovenia, Turkey, Turkmenistan, Ukraine; Asia, Southeast Asia, Southern Asia = Cambodia, China, India, Japan, Korea, Laos, Mongolia, Pakistan, Thailand; Oceania = Australia, Fiji, New Zealand, Palau; Africa = Cameroon, Botswana, Congo, Egypt, Eritrea, Ghana, Kenya, Libya, Madagascar, Morocco, Nigeria, Senegal, South Africa, Sudan, Tanzania, Tunisia, Uganda; Middle East = Cyprus, Iran, Iraq, Israel, Jordan, Lebanon, "Near East," Palestine, Syria, United Arab Emirates. 


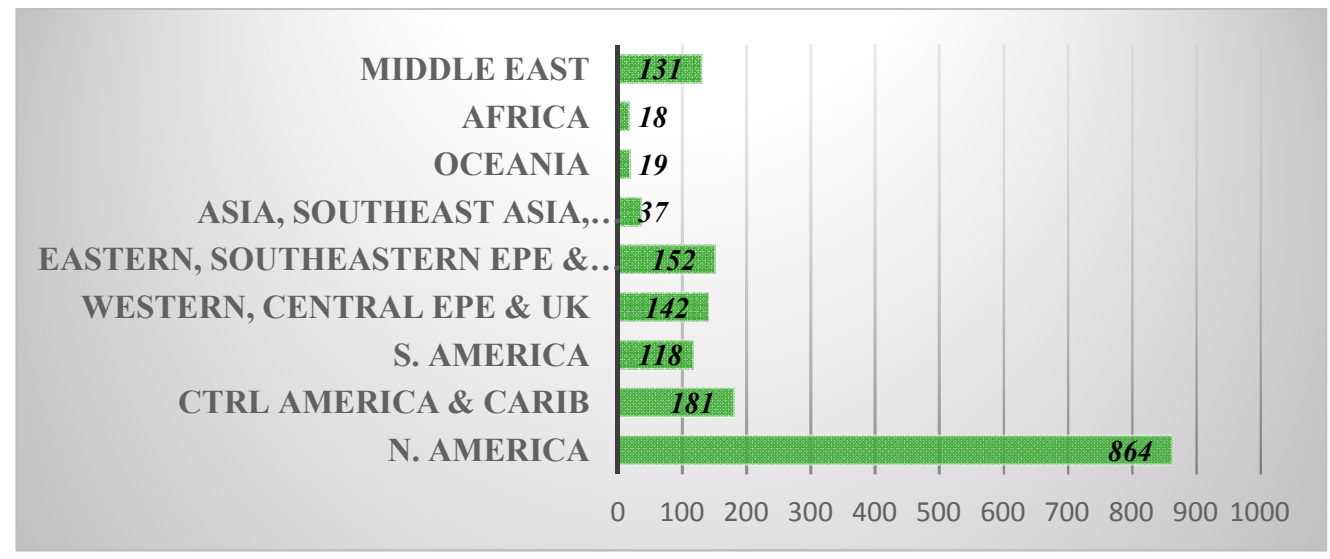

Figure 1. Aggregate locations of archaeologists' reported experiences with looting.

Further, personal experience with looting was more commonly reported among participants with more time and experience in the field. This is not unexpected in that they simply have had more opportunities throughout their careers to encounter looting or evidence of it. Additionally, these experiences with looting were not one-time occurrences; the overwhelming majority $(92 \%)$ of participants indicated that they had observed looting on more than one archaeological site, and that each of those sites had been looted on more than one occasion. As one archaeologist remarked, "I can't think of a Maya site [I've seen] without looter pits."

It is reasonable to conclude that looting is an iterative phenomenon that occurs on more archaeological sites than not. In fact, a personal encounter with looting appears to be so commonplace an occurrence that, as one surveyed archaeologist working in Cyprus noted, "[we're taught that] the possibility of meet[ing] with looters while you're working on site is just a given; it's just a known aspect of archaeological fieldwork."

While the majority of archaeologists report having had experiences with on-site looting ex post facto in the field (e.g., missing tools, equipment, and artifacts; collapsed architectural features; and holes, site disarrangement, or other visible effects), nearly one-quarter (24.1\%) of respondents have in fact been eyewitnesses to looting activity in progress on site. When field archaeologists do interact with looters, it is more likely to be an off-site occurrence. In fact, $87.1 \%$ of respondents reported having interacted off-site with looters-both admitted and suspected. The contexts of these off-site experiences included casual conversations between archaeologist and looter, and many archaeologists reported that many looters have spoken openly and freely with them about their own participation in unauthorized digging. Other archaeologists talked about having been specifically approached off-site by looters, who presented them with looted items, seeking respondents' approval, admiration, or confirmation:

They [looters] are actually proud of what they are finding... Thus they view themselves as helping to salvage what can be salvaged.

—Archaeologist \#31087, western United States

[Looters have] a desire to obtain insight on cultural significance/interpretation and commercial value specific to the specimen(s).

-Archaeologist \#33562, southern/southeastern United States

Nearly half of the total surveyed archaeologists (49\%) also reported having been offered looted items for sale:

Sometimes I am approached because [they] don't know I am an archaeologist. Other times I am approached because individuals think that because I am an archaeologist I will want to buy what they have looted. 
Figure 2 below shows this data broken down by the top fieldwork locations in which archaeologists reported having been asked to purchase a looted item on at least one occasion:

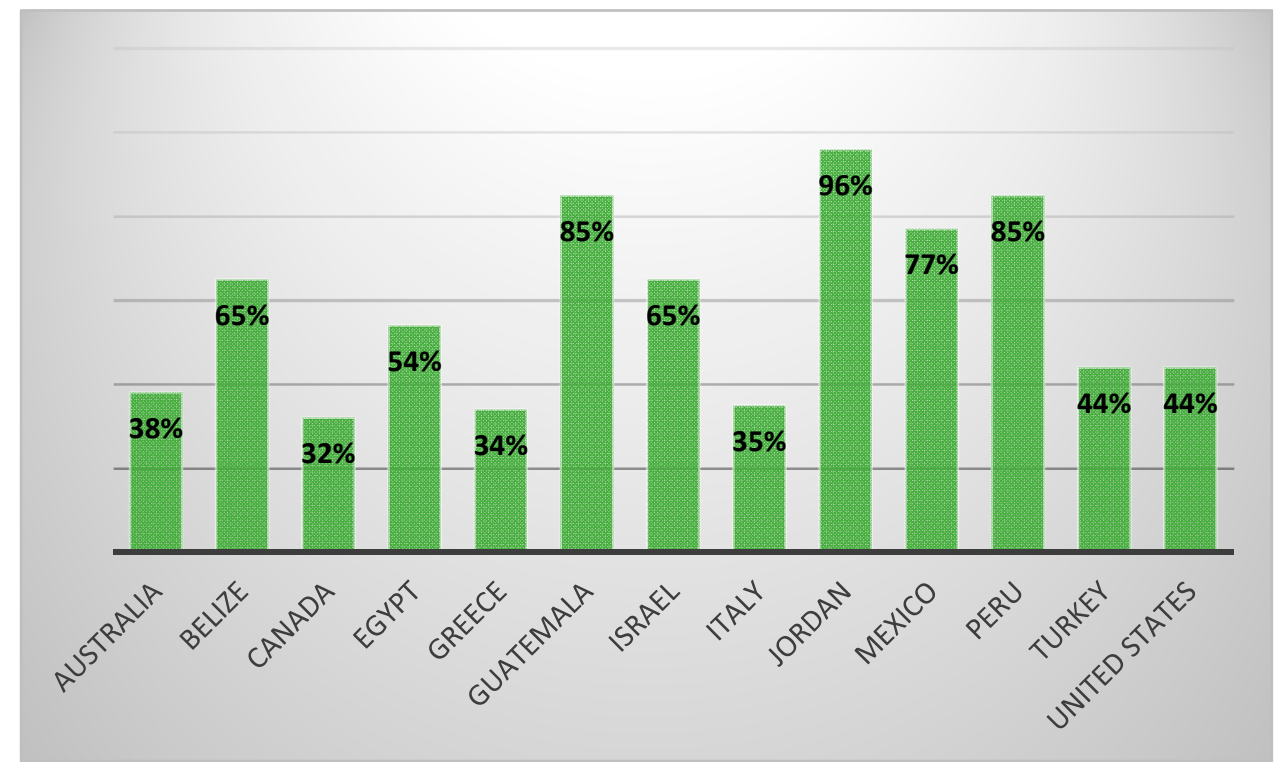

Figure 2. \% Respondents solicited off-site for purchase of looted objects.

Being offered an item of questionable provenance for purchase is not an experience limited to one country or part of the world for archaeologists; rather, it appears to be a commonplace occurrence.

The data thus far can be summarized as such: site looting is an endemic, iterative activity with which the vast majority of field archaeologists have had personal experience. It is so commonplace, in fact, that it is often considered an inevitable part of the field archaeological experience. When looting is encountered in the field, it is much more common for archaeologists to witness the aftermath of looting, rather than to encounter looting activity in progress. This makes sense, given that undocumented digging is necessarily clandestine, so much of it occurs at night when archaeologists are off-site. ${ }^{13}$ This is not to say, however, that field archaeologists never have personal interactions with looters, but when this does occur, it is much more likely to happen off-site in a variety of social contexts.

\section{Archaeologists' Reported Responses to Looting}

When surveyed archaeologists have witnessed looting in progress on site or its after-effects, what actions do they take? Figure 3 below shows varying responses; these responses can be aggregated into three broad categories: internal action, external action, and inaction.

As shown above, when field archaeologists choose to handle the matter internally, the most common action is to document the evidence of looting activity and discuss it with other team members before moving on. In terms of external responses-that is, notification of some external authority-few archaeologists took only a single action. Rather, most archaeologists first document the looting, notify other team members, and then contact a relevant external authority, which is typically some sort of local authority with oversight of archaeological sites and remains. In some countries, the notified agency could be a specific police unit tasked with cultural heritage protection (e.g., Italy's Comando Carabinieri per la Tutela Patrimonio Culturale); in others, it might be a local unit of an archaeological authority (e.g., Greece's Archaeological Service has nearly 50 departments located throughout the country which,

13 Many Italian tombaroli (tomb-robbers), for example, report having had to move their illicit digging activities to nighttime in recent years due to the creation of art and antiquities squads across Italian law enforcement agencies (Perticarari and Giuntani 1986). 
among other things, supervise local archaeological projects). Beyond these steps, about one-quarter of archaeologists reported having taken this additional step of some type of external notification.

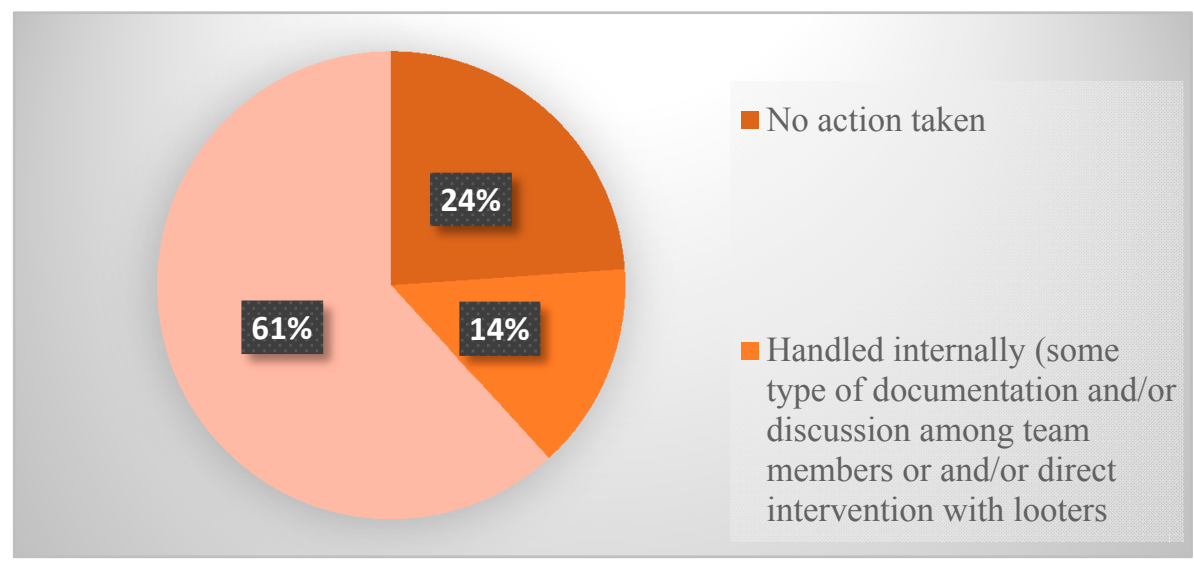

Figure 3. Actions taken by archaeologists upon observance of looting, in aggregate.

For those who actually observed illicit digging activity in progress, several respondents personally confronted the looters:

I drove towards [the looters], scaring them off; then I talked with [the looters] and attempted to convince them to stop.

-Archaeologist No. 29761, Southern coast of Peru

I confronted the looters and asked them to stop and empty their pockets. Then I explained cultural resource laws ... and the importance of conservation.

\section{-Archaeologist \#8320, Northwest Plains, United States}

For those archaeologists who reported being approached off-site by both admitted and suspected looters, many reported having tried to turn the encounter into an educational opportunity:

I've had long discussions with local Mayans regarding what is legal and what is not, as well as why protecting the archaeological record benefits their community.

-Archaeologist \#17491, Yucatan, Mexico

I've urged holders of looted items to donate them to a local museum.

—Archaeologist \#29761, Southern coast of Peru

The common thread in these reported experiences is archaeologists' efforts to ameliorate the encounter by turning it into an impromptu opportunity for education and outreach. While noble in intent, this response is hardly realistic for all archaeologists who encounter looting in flagrante delicto.

In sum, more than half of responding field archaeologists choose to document looting or evidence of it before notifying an external authority of some sort. Usually, this is contact with a local archaeological authority, and sometimes subsequently a law enforcement authority. Slightly more often than not, archaeologists incorporate the notification of appropriate authorities into their actions, and where possible, a number of field archaeologists choose to handle their firsthand experiences with looting as an opportunity to advocate the preservation of archaeological heritage. All of these actions appear to be not only congruent with archaeologists' practice and promotion of stewardship of 
the archaeological record, ${ }^{14}$ but are also consistent with domestic legislation-most countries have criminalized archaeological site looting. ${ }^{15}$

But what about the other half of respondents who, upon encountering looting, evidence of looting, or even looters themselves in the field, and despite statutory criminalization of looting, reported that they did not alert any external authority and instead either chose only to handle the matter internally through project documentation, or chose to take no action at all? A variety of explanations was offered for this. Some noted the futility of such action, suggesting that law enforcement or local archaeological authorities were simply outnumbered, ineffective, uninterested, or even complicit:

In the Mimbres Valley it is certainly taken seriously, but with the vast amount of land and a limited number of law enforcement officers this is more easily said than done...

\section{-Archaeologist 28792, Southwestern United States}

Everyone in the Maya lowlands knows the frequency of looting [so] there is no reason to appear so naïve as to notify authorities.

—Archaeologist \#8593, Guatemala

[Law enforcement] rarely do patrols and no one has been prosecuted from the [looted] sites where I work.

—Archaeologist \#28696, Midwestern United States

Law enforcement and judges [do] not take the [looting] laws seriously.

—Archaeologist \#37420, Northwestern United States

It can be dangerous to intervene personally in a looting incident as police may be complicit or disinterested.

—Archaeologist \#17551, United Kingdom

Other archaeologists reported feeling utterly powerless in stopping the looting, and that criminalization as such was an ineffective deterrent. These archaeologists chose not to take any external action either, as they felt it would be futile, ineffective, or even dangerous:

[The looters] think that archaeologists do not have the power to denounce them, and they are usually right.

-Archaeologist 6916, Switzerland

The punishment is too low [for looting] to bother.

-Archaeologist \#25102, Austria

They [the looters] had guns.

—Archaeologist 32605, Southwestern United States

I have been advised never to approach people we find on sites without a way to contact law enforcement.

—Archaeologist \#27046, Southeastern United States

14 Among other tenets, most archaeological codes of ethics include language emphasizing the archaeologist's role in recording, conserving, preserving, and stewardship of the archaeological record. See, for example, the Society for American Archaeology's Principles of Archaeological Ethics, adopted 1996. Available online at: http:/ /www.saa.org.

15 Most countries have domestic statutory schemes that criminalize archaeological site looting. The archaeological record is usually construed as State property, the unpermitted removal and export of which is tantamount to theft. The United States is somewhat of an interesting outlier in that archaeological site looting is only criminalized as theft on federal/state/tribal lands-not on private property-however, given that a significant portion of the United States is in fact public land, looting is still largely criminalized in effect across the country. See 16 U.S.C. § 470ee(a) (2012). 
One archaeologist suggested that she took no external action because the looters earn so little from their finds and that items are simply not valuable enough to bother reporting:

Some people who actually conduct the looting in my area and either keep what they find or sell it to small-scale dealers and don't earn significant quantities.

—Archaeologist \#35983, Peru

Other archaeologists noted that perhaps reticence to contact external authorities - or take any action whatsoever-regarding site looting was due, in part, to ignorance or even indifference among field archaeologists themselves:

Many archaeologists working outside their home countries are not well enough informed about international conventions and local laws. And frankly, a lot of archaeologists just don't care about looting until it happens on their sites.

$$
\text { —Archaeologist \#29281, Belize }
$$

I think most archaeologists know instinctively that looting is wrong, but they're ill-prepared to deal with it or unsure what to do about it.

-Archaeologist \#1830, Britain

Some [archaeologists] are scared of discussing looting, maybe because of funding issues, or they encourage it but don't want to admit it.

—Archaeologist \#1141, United States

Maybe after I get tenure I can be more vocal [about looting], right now I'm keeping my mouth shut.

—Archaeologist \#43726, Peru \& Mexico

Respondent \#1141 appears to suggest that archaeologists may choose to either document the looting and move on, or do nothing about it altogether, because to do so could have far-reaching implications for their research and, in turn, their careers. As Brodie and Luke (2006) have noted, financial support for archaeological excavations often comes indirectly from private collectors, and many archaeologists are employed by museums or universities whose donors and trustees are often antiquities collectors. Beyond issues of project funding, archaeological fieldwork and study permits can also be difficult to obtain. For example, if an archaeologist wanted to study a particular object held in a museum's collection, she would be required to submit a study application whose acceptance is subject to the discretion of that museum. While it is no secret that many museums have a long and troubled history with acquiring looted antiquities for their collections, ${ }^{16}$ for an archaeologist to suggest that a particular museum's collecting agenda could in some way aggravate illicit digging and site destruction might very well hamper her ability to receive a study permit, excavation permit, or project funding. These difficulties can, in turn, jeopardize her research productivity, which, at least in academia, is a salient factor on which scholars are evaluated for promotion and tenure. ${ }^{17}$

That archaeological fieldwork is subject to a host of complex political relationships among its stakeholders is no surprise. Social science of any sort is inherently and inevitably political, and this is reflected in the spectrum of surveyed archaeologists' attitudes toward looting activity. The variation in archaeologists' responses to illicit digging is a clear reflection of the highly nuanced socioeconomic,

16 Cf., for example, (Felch and Frammolino 2011).

17 Cf., for example, the Archaeological Institute of America's suggested indices for the evaluation of classical archaeologists for promotion and/or tenure at North American colleges and Universities: conducting data collection, obtaining research funding and permits, and research publication. Available online at https://www.archaeological.org/careers/tenure (AIA Higher Education Committee 2016) 
political contexts, legal frameworks, and cultural contingencies which lend shape and meaning to illicit digging from one particular site to the next.

By far the most common explanation among surveyed archaeologists as to why many of them chose to either simply address the matter internally or do nothing at all upon encountering looting or looters on- and off-site had to do with the nature of an archaeologist's relationship with the communities within which she works. That is, some archaeologists choose not to report looting activity or looted items largely out of sympathy for the locals conducting the looting:

Frankly I'm ambivalent towards looting activities because it is often economic necessity that prompts people to loot archaeological sites.

—Archaeologist \#29761, Peru

When I have been offered by someone to buy or look at looted materials, it has always been by local people in the communities in which I worked. So, I never tried to report it to any higher authorities.

—Archaeologist \#15337, Belize

I did nothing when offered looted items for sale in Peru and Mexico because the items were small and people involved were clearly at the lowest level of the trade.

-Archaeologist \#43726, Peru \& Mexico

I find it hard to blame the locals, since looted material can bring in over a year or two worth of income, and these people tend to be poor farmers trying to support their families.

—Archaeologist \#20734, Belize

I worked with some locals who would protect me with their lives, and I them. I know they had looted in the past ... They are not getting rich by looting. Although they may be getting by with looting.

—Archaeologist \#11566, Belize

Other archaeologists worried that, were they to report to an external authority, they risked alienating the communities in which they work, which could encourage further looting or altogether jeopardize the ability to continue fieldwork there:

It's hard to confront the looters when they live there and we [the archaeologists] do not. To confront them risks pissing them off and could even lead to increased looting on sites where they've seen us working after we leave.

$$
\text { -Archaeologist \#685, United States }
$$

For whatever reason, a field archaeologist may find herself in an uncomfortable predicament: call out the looters on their destructive behavior and risk jeopardizing not only her own safety but her fieldwork activities, research productivity, and career trajectory by damaging relations with her host community; or, do nothing and risk enabling the continued destruction of archaeological resources.

\section{Justifications for Nonreporting to External Authorities}

Justifications for archaeologists' decisions not to contact relevant external archaeological or law enforcement authorities or to take no action at all can be aggregated as such:

- Sympathy for the looters because they have no alternative means of economic gain (e.g., "subsistence digging") and are therefore victimized by the demand for antiquities generated in wealthier market countries, or because recreational digging is an established cultural tradition; 
- Reporting to local archaeological or law enforcement authorities is useless because they are ill-equipped, indifferent, or in some cases, themselves participants in looting;

- Career-driven concerns to preserve relationships with host communities, fieldwork opportunities, and research productivity;

- Patent indifference to site looting.

Most, if not all, of these rationalizations are fundamentally troubling in one way or another.

\subsection{Indifference}

First, a field archaeologist's blatant apathy toward looting and the toll it takes on the archaeological record seems wholly incompatible with even the most basic of archaeological ethics focused on stewardship, education, and outreach. It is also untenable given the intellectual value assigned to archaeological resources, which provides the foundation for those ethics. This disinterest in taking action in the face of looting among some archaeologists is but another context in which an archaeologist's action — or in this case, inaction — entangles further the practice of archaeology with economic exploitation of the archaeological record (Lynott 1997; Wylie 1996).

I do not suggest that this "ethical passivity" of sorts among some archaeologists is the same as an active endorsement of looting, but neither does it, in my view, overtly proscribe it. An archaeologist's indifference to looting as evidenced in a subsequent decision not to report can be viewed as a tacit failure to care. Put simply, this failure to care seems diametrically opposed to what archaeologists purport to care about. That looting damages the archaeological record, and there are archaeologists who, in the words of Archaeologist \#1830, "couldn't care less about looting," makes archaeologists' conventional platitudes about their commitment to the stewardship of archaeological resources disingenuous at best and ethically questionable at worst. Indifference about and failure to report site looting is as surprising as it is counterintuitive and may be an indication that some archaeologists really do not genuinely care about the stated preservationist goals of the discipline of archaeology. Or perhaps some archaeologists remain insouciant with looting only "until it happens on their sites"; continues Archaeologist \#29281, "that's when they really get hot and bothered about it-when it happens to [their] project-it's like they don't really care until it happens to them, and then they take it so personal."

This is not to suggest, however, that the archaeologist who does not care about looting happening elsewhere is uncaring about any and all things archaeological. There is, as discussed above, his career trajectory to be concerned about. Perhaps an archaeologist is very genuinely concerned about the preservation of resources, but this is outweighed by pragmatic concern for the preservation of his career. As discussed above, the drawing of external, official attention to looting activity could very well generate feelings of mistrust or even hostility within a host community, and an archaeologist's inability to access archaeological resources could put his career progression into jeopardy.

Whether or not it is motivated by genuine apathy—or, apathy that is as situationally motivated as it is self-interested-this rationalization for inactivity is noteworthy in that it reflects not only a fundamental disconnect with established ethical principles of archaeology, ${ }^{18}$ but also a self-centered willingness to turn a blind eye to site looting for one's own professional benefit. After all, the professional pressures of scholarship and publication within the culture of academia are not insignificant. An archaeologist's research productivity depends heavily upon the amicability of his relationships to and collaboration with a host community, and there has been a perceptible shift in the "decolonization" of many archaeological projects away from research "'on and for' communities toward research 'by and with' them" (Atalay 2012, p. 7). A field archaeologist's decision not to report

18 See, for example, the Archaeological Institute of America's Code of Ethics ("The AIA is dedicated ... to the protection and preservation of the world's archaeological resources" (Principle \#1); the Society for American Archaeology's Principles of Archaeological Ethics (Principle No. 1, "Stewardship," et seq.). 
looting activity to an external authority may be preservative of shared authority in such democratized research collaborations and may also help to maintain the public's interest in and engagement with archaeological resources (Atalay 2012; Nicholas et al. 2008; Little 2007). ${ }^{19}$

The beneficence of such collaborations, however, is hardly one-sided, and the fact that many archaeologists seem frank about attaching professional advancement and career success to their field research productivity suggests a different sort of exploitation of the archaeological record. After all, digging at archaeological sites-whether authorized or unauthorized-presupposes some inherent value of archaeological resources. A looter connects an antiquity's value to its commercial value as a commodity; an archaeologist connects an antiquity's value to the information it may yield about the human past as fodder for scholarship. Both are appropriative practices, both are inevitably destructive to some degree, and one is no more value-neutral than the other. In fact, an archaeologist's valuation of resources could be viewed as another sort of value-laden commodification; perhaps the price of his career success might be bought, in part, by research productivity, ${ }^{20}$ which is at least partially contingent upon getting along with the locals.

In sum, a field archaeologist who does not take steps to notify an external authority after a personal encounter with looting may have done so out of either patent indifference or professional self-interest; whether these are ethically defensible justifications is a different question. Archaeologists have long held that their vested interests in physical remains of the human past are scientific and/or academic, and that preservation of the archaeological record and information derived from it are a public good. The social value of archaeological knowledge is typically used to buttress archaeologists' claims to priority of access to and control of the archaeological record as well whatever information is gleaned from it (Nicholas and Wylie 2009). While an archaeologist's stated interest in archaeological objects may be oriented toward the public good, his private interests are no less served than a looter's. Put another way, both archaeologists and looters assign value-laden importance to and exercise appropriative behavior toward archaeological objects; both are consumers of archaeology; both use archaeology in some manner to make a living; and whether or not it is a stated central aim, both personally benefit from such consumption. Based on archaeologists' feedback, as presented above, it is certainly possible, then, that both groups' "competing" interests in the archaeological record are not so diametrically opposed after all.

\subsection{Ineffectiveness}

Negative perceptions of law enforcement authorities-that is, impressions that police are incompetent, ill-equipped, inefficient, or altogether indifferent-are other common explanations for under-reporting or non-reporting of crime in both developed and developing countries (Boateng 2012, 2016; Goudriaan et al. 2006; Kääriäinen and Sirén 2011; Marenin 1997; Rosenbaum et al. 2005; Sunshine and Tyler 2003). As evidenced above, this is also a pragmatic rationale common among field archaeologists who choose not to contact external archaeological or law enforcement authorities after a personal encounter with looting. There is a pragmatic cost, however, to this inaction. First, non-reporting contributes to the perception that looting is not as pervasive a phenomenon as archaeologists say it is. This is helpful for those who champion an open antiquities trade-namely, collectors and dealers-who insist that the role looting plays in the antiquities trade is greatly exaggerated (Brodie 2002;

19 The goal of including associated indigenous peoples in archaeological fieldwork is reflected in numerous places in the World Archaeological Congress' (WAC) First Code of Ethics Principles, adopted in 1990. See http:/ /worldarch.org/code-of-ethics/.

20 See the Archaeological Institute of America's 10 recommended criteria by which to evaluate classical archaeologists being considered for promotion and/or tenure. Every consideration listed has something to do with research productivity (e.g., No. 1, "Data Collection"; No. 2, "Research Permits"; No. 3, "Funding") and subsequent publishing productivity (e.g., No. 4, "Multiple Authorship"; No. 5, "Pace of Research"; No. 6, "Access to Images and Publications"; No. 7, "Publication in Digital Formats"; No. 8, "Publication in International Venues"; No. 9, "Citation Indices"; No. 10, "Leadership Roles for Younger, Pre-Tenure Scholars"). Full text available online at: https://www.archaeological.org/sites/default/files/files/ AIA\%20Tenure\%20and\%20Promotion\%20Considerations.pdf. 
Renfrew 2002). Non-reporting also biases further ${ }^{21}$ any official estimates of looting, so any economic modeling, policy, or practice based on official data are inherently unreliable.

Official estimates are the "empirical basis for practically all comparative research, findings, theorizing on crime and social change, and criminal justice policies" (Marenin 1997), and as Brodie et al. (2001, p. 1) note, "when the hard political decisions are made, it is figures that count." Looting data is similarly impacted by non-reporting and has a similar attenuating effect. Non-reporting of looting may be a convenient decision for archaeologists in the short term, but in the long term, it confounds official data and any sort of policy or practice developed from it. Non-reporting also hampers attempts to estimate the size and nature of transnational markets for particular types of looted objects, which precludes any realistic assessment of the scope and nature of any appropriate counter-measures needed to curb it. To be sure, non-reporting of looting is certainly not conducive to deterring it.

That some field archaeologists decline to report looting because of the inability of law enforcement or other authorities to respond becomes even less tenable when considered within an international legislative context. Police incompetency and ineffectiveness are often couched in terms of corruption, and worldwide efforts to professionalize law enforcement and increase training, competency, and anticorruption among police agencies around the world are underway. Adopted in 2005, the United Nations Convention against Corruption has now been ratified by nearly all countries around the world, and the addition of its specific provisions on asset recovery was led by "source" nations concerned about culturally significant items being stolen and illegally exported to "demand" nations. ${ }^{22}$ In a similar vein, the United Nations Office of Drugs and Crime (UNODC) has also developed model agreements and treaties on extradition, including the transfer of criminal proceedings, foreign prisoners, the sharing of confiscated proceeds of crime, and mutual legal assistance. ${ }^{23}$ In short, this means that even countries with ineffectual local police now have multiple viable avenues through which claims can be made for the return of illicitly obtained antiquities. If an archaeologist's decision not to report looting is because the inefficacy of local law enforcement is perceived to preclude any practicable channels through which to pursue looted antiquities, this rationale is short-sighted if not wholly inaccurate. This rationale also conveniently plays right into the hands of the pro-market polemicists, among whom this is commonly cited not only in justifying their "rescuing" of cultural objects but in shaming source countries for their "inability" to manage their own cultural heritage (cf. Efrat 2009; Prescott and Omland 2003).

\subsection{Indigence}

When archaeologists choose not to notify external authorities after witnessing looting or evidence of it, it is often reportedly out of concern for the welfare of those doing the illicit digging whom they view as "victims." These archaeologists make victims of diggers on two fronts. First, unstable economic conditions are blamed for causing some individuals to turn to looting out of desperation as a way to make a living. In this sense, it is general economic circumstance that does the victimizing. At least some illicit digging around the world is reportedly done as a "way of surviving poverty" (Yahya 2010, pp. 97-98), a "desperate effort to feed families" (Politis 1994, p. 15), and as Hardy (2015) observes, "sometimes 'looting' is the only thing that does feed the 'looters'" (p. 235, emphasis in

21 Official estimates of site looting are unreliable in that it is often conflated into art or cultural property crimes, and under-reporting of cultural property crime is already a problem (Tijhuis 2006). INTERPOL, for example, reports that fewer than half of its member countries regularly report cultural property crimes (INTERPOL 2007).

22 See United Nations Convention against Corruption Chapter V, "Asset Recovery, Article 51 et seq. Available online at: https://www.unodc.org/documents/treaties/UNCAC/Publications/Convention/08-50026_E.pdf.

23 See Compendium of United Nations standards and norms in crime prevention and criminal justice (available online at: http://www.unodc.org/pdf/compendium/compendium_2006_part_02_01.pdf) and United Nations Protecting Cultural Heritage: An Imperative for Humanity, available online at: http:/ / www.unodc.org/documents/publications/SRIUN_ Protecting_Cultural_Heritage_2016.09.12_LR.pdf. 
original). For these archaeologists, diggers are "victims" who are "poor, malnourished farmers without money for seed, and without sufficient land to practice subsistence agriculture" (Matsuda 1998, p. 88). This is looting motivated by economic despair, and "[i]n private, a great many archaeologists are 'realists' ... with a closeted sympathy for the poor indigenous people they hire to work as camp help and grunt laborers" (p. 83).

Archaeologists sympathetic to these "victim-looters" suggest that they are also victimized by the broader, insatiable greed — the "lust for antiquities" among collectors (Muscarella 2000, p. 12)—who, as Elia (1993) famously wrote, "are the real looters" (p. 69). Looters are thus "victims of a global market, exploited by the demands and desires of dealers and collectors, who are the real villains" (Hollowell 2006a, p. 78). In other words, many archaeologists choose not to report looting on the grounds that the looters are victimized by both local and global economic conditions. In their view, alerting authorities could preclude looters from finding saleable items, the proceeds from which are a survival necessity.

These archaeologists appear to suggest that not everyone who participates in looting at an archaeological site is himself a "looter" in a conventional sense-in other words, a criminal-whether or not there is domestic legislation that codifies it as such. This sentiment is echoed in archaeologists' responses below:

This area is so poverty-ridden that it is impossible to blame the looting on people who otherwise have no or few economic resources ... [I]llegal economic activities are frequently the only recourse left to a growing number of people.

—Archaeologist \#31087, Mexico

I am generally sympathetic with villagers and farmers who are poor.

-Archaeologist \#26800, Turkey

Anyone who is desperate enough to feed their family may resort to such undertakings because the high moral road is simply not an option. I don't like to put excuses on it, but it is what it is.

—Archaeologist \#5977, Southeastern United States

... the people at the bottom of the looting chain are often without much in the way of financial means and may be looting as a means of survival, and are "criminals" only in the same sense as Jean Valjean.

—Archaeologist \#12133, Ontario, Canada

\section{Looters as Victims or Criminals}

In rationalizing their non-reporting, some archaeologists' characterizations of some looters as "glocal victims" suggests that they view other looters as "glocal criminals." From a criminological perspective, this dichotomy of sorts has been largely neglected, with the bulk of scholarly treatment of unprovenanced antiquities focusing on the "transit" and "demand" points. For example, antiquities smuggling has been studied in how it overlaps with organized crime, other forms of trafficking, and transnational criminal networks (Mackenzie and Davis 2014; Dietzler 2013; Bowman Proulx 2010; Tijhuis 2006) its links to the funding of insurgencies (Smith-Meyer 2017; De la Torre 2006); the proliferation of fakes and forgeries (Halperin 2017; Kantchev 2017); and comparison of dealers and collectors to white collar criminals (Mackenzie 2005). Within these contexts, the criminality of persons involved is straightforward and uncontested. When it was discovered that hijacker Mohamed Atta had attempted to peddle stolen Afghan antiquities in an effort to help finance the terrorist attacks of 11 September 2001 (De la Torre 2006), or when looted antiquities in the Metropolitan Museum of Art in New York were traced back to organized tomb-robbing activities connected to the Italian Mafia (Stille 1999), 
no one thought twice about characterizing the looters as "criminals," not "victims." There was no waffling or ethical ambiguity about whether these sorts of illicit diggers were criminals.

In fact, no one disputes that there are distinct criminal dynamics in moving, fencing, selling, and buying unprovenanced antiquities, and it is not at all uncommon to find criminologically oriented language employed to describe these phenomena. ${ }^{24}$ Terms such as plunder (Brown 2015; Andrews 2003; rob/robbery/robber) (Bohstrom 2017; Mueller 2016; Lehr 2013; Hamblin 1970; theft/thievery/thieves) (Harari 2017; Akhtar 2012; Bowman Proulx 2011; Bogdanos 2005; steal/stolen) (Glazer 2017; Thompson 2015; vandal/vandalism) (Steinbuch 2017; Greenberg 2016; mafia/mob) (Harkin 2016; Nadeau 2016; cultural racketeering) (Lehr 2013; heritage/culture crime, crime against culture) (Fincham 2014; Sadeghi 2014; Chabiera 2011; Bowman Proulx 2008) are routinely used to describe the unauthorized removal and subsequent movement and sale of culturally significant material from the archaeological record. The theme at a recent international conference on protecting cultural heritage even focused on "challenges for criminal justice," 25 at which Fincham (2014) referenced cultural heritage as a matter to be "policed" and an offense in which "the 'thief' could be prosecuted, and the criminal law will "punish someone who has taken a beautiful work, [allow] prosecutors and law enforcement to show that serious thefts will not be tolerated, and ... ideally [send] a message to future thieves to refrain from further theft" (p. 87).

Even the term looting — strictly by statutory definition—is criminal (e.g., stealing something from some place, often during times of political turmoil), and while looting is commonly used to describe all forms of criminal digging, most archaeologists seem to stop short of dismissing all looters as criminals. Whether or not a country has criminalized looting, there is nonetheless dissent about whether everyone engaged in unauthorized digging is behaving criminally. That is, "looting" is generally equated legally with "crime," despite the fact that, from many archaeologists' points of view, those doing the actual digging may or may not, in fact, be "criminals" (Hollowell 2006b).

That many archaeologists appear to be comfortable in construing some looters as victims while others are criminals provides a morally convenient shift in culpability away from "victimized" diggers, in order to place the blame squarely on individuals who instead illegally move antiquities or create the demand for them. Both "criminal-looters" and "victim-looters" commodify antiquities, and both seek to remove undocumented antiquities from sites for a commercial gain of sorts. Both activities are largely criminalized by statute. But when an archaeologist differentiates the two, the negativity-if not illegality-inherent in the latter motivation for looting appears to be tempered by the attachment of "victim." According to many archaeologists, not all looters are, in fact, looters. To suggest that illegal digging motivated by greed is different from illegal digging motivated by need provides a certain moral accommodation in reviling and dismissing the antiquities trade in its entirety as a criminally exploitative endeavor while conveniently sidestepping the problem of specific criminal condemnation of "victim-looters." Instead, for many archaeologists, "looter-victims" apparently lack criminal agency because they are victims whose illicit activities are driven by other people's criminality.

This nuanced consideration of "looting" among archaeologists shows that not each and every "looter" whom they might meet in the field is considered "criminal," and as Alderman (2010, p. 93) rightly points out, what is legal and what is ethical can often part ways: "Sometimes the law is consistent with what is generally perceived as ethical, but quite often something can be right even if

24 Given the criminality embedded in various points of the trade in unprovenanced antiquities, it is not at all surprising that national and international responses also treat the matter as criminal. The FBI investigates, for example, investigates illicitly obtained antiquities within its Art Crime Team, INTERPOL's international database of stolen art works includes stolen and smuggled antiquities, and antiquities trafficking is an offense enumerated in the 2000 United Nations Convention against Transnational Organized Crime.

25 International conference on Protecting Cultural Heritage as a Common Good of Humanity: A Challenge for Criminal Justice, 13-15 December 2013. Select conference papers compiled and published by the International Scientific and Professional Advisory Council of the United Nations Crime Prevention and Criminal Justice Programme. Retrieved 20 April 2018 online: https://www.unodc.org/documents/congress/background-information/Transnational_Organized_Crime/ISPAC_ Protecting_Cultural_Heritage_2014.pdf. 
it's illegal or, conversely, it can be wrong even if not proscribed" (emphasis in original). Legality and ethics are often at odds with one another, and as Yates (2016) notes, perhaps the criminalization of all illicit digging is questionable, especially in terms of the attachment of criminal sanctions. Put simply, just because illicit digging at archaeological sites may be criminalized in a domestic statute does not mean that, in the minds of either diggers or field archaeologists, everyone doing it is himself a criminal.

The perception that not all looting may be criminal has not precluded many countries from indiscriminately criminalizing it. In their study of 46 countries that criminalized illicit excavation and export of antiquities, Alderman and Dahm (2014) found that the majority allowed for both fines and incarceration as punishment (p. 442). Where unauthorized digging and export are not punished equally, impoverished diggers ("victims" of economic circumstance) in developing nations are typically punished less harshly (p. 452). In wealthier nations, illegal digging (by "professionals" or "criminals") and exporting receive fairly similar punishments. While collectively criminally punished, these statutory disparities across countries suggest that archaeologists are not the only ones to consider that not all who engage in "looting" are consider equally culpable. Indiscriminate characterization of all illicit digging as "looting activity" — and therefore, an activity with criminal undertones—potentially masks these important differences. In sum, many archaeologists seem to have no trouble talking about archaeological site looting as crime in a general sense, but when it comes to assigning specific criminal culpability to specific individuals who actually carry out the looting in areas where they work, many archaeologists are quick to point out that it depends on a looter's specific motivations. The looting that is undertaken out of economic need, while unfortunate, appears to be considered justifiable or excusable among many archaeologists. Motivations for looting activity do not, however, "cancel out" the statutory criminality of a looter's activities.

Certainly not all archaeologists view some looters as criminals while others are victims and mere pawns who are exploited in the antiquities trade. Rather, there are a number of archaeologists who perceive all illegal digging to be criminal, or that it should be codified and treated as such. For them, it matters not whether looting occurs of economic necessity. As such, former UNESCO Director General Koïchiro Matsuura called illicit digging a "crime against culture," as did Bowman Proulx (2008) ${ }^{26}$; Howard et al. (2016) even declared some manifestations to be a "cultural genocide" 27 of sorts. Wrote Yahya (2010), "We should stand firm against activities such as illicit digging, grave robbing and above all trading in antiquities, and reject any excuses presented by the diggers and dealers to justify their actions" (p. 99). Other archaeologists have gone so far as to suggest that looting can only be curbed with violence, asserting that they "would like to see helicopters flying over [Iraqi archaeological sites] so that people know there is a real price to looting this stuff ... You have got to kill some people to stop this" (archaeologist Elizabeth Stone, quoted in Bennett 2003, para. 3; also quoted in Kennedy 2003, para. 2) and that "these people are stealing material from the whole of mankind. If they steal from mankind I would say that it is fair they should be shot" (Lovell 2003, para. 1). For these archaeologists, looters are generally "poor people [who] are immoral, motivated by greed, plunder for profit, and are exploited by antiquarians" (Matsuda 1998, p. 84). In this vein, there is little if any ethical latitude for a viable affirmative defense to the crime of illegal excavation:

To me, theft is theft. If impoverished people were helping themselves or being encouraged to help themselves to other kinds of objects or materials on public lands or on other people's property, the behavior would not be tolerated. Why is it OK to help yourself to an archaeological site? I don't think anyone suggests that bank robbers are just victims of economic exploitation.

26 (UNESCO 2001).

27 See (Howard et al. 2016). 
Looting applies whether we are talking about the Chinese army, the Italian mafia, or the impoverished peasant in Peru. Whether they all deserve the same punishment if caught is a matter for legal systems to decide. To me it is all looting, and the term as denoting a crime is similar to the range between misdemeanor to felony, from petty larceny to grand larceny. It is all theft in one form or another.

Archaeologists' opinions "represent a continuum of predispositions-from sympathy to villainization" (Matsuda 1998, p. 88); this is evident in the divergence of accounts among field archaeologists' reported personal encounters with and responses to it. Looting is likely to have been criminalized by statute, ${ }^{28}$ but this does not always have much, if any, bearing on whether an archaeologist views an unauthorized excavator as "looter," "criminal," or "victim."

Some illegal diggers are considered criminals and others victims-this is not a common distinction made in domestic statutory schemes or archaeological rhetoric. Even archaeologists who suggest that the vast majority of unauthorized digging is done out of economic insecurity still talk about it as "looting," "theft," 29 "stealing," 30 and "robbery,"31 while simultaneously stopping short of calling such looters "thieves" and "robbers." Why are archaeologists likened to "detectives" (Holtorf 2005), looting called "time crime," 32 and looted sites referred to as "crime scenes," 33 but most "looters" are instead "subsistence diggers" or "victims"? Is it not somewhat contradictory—or at the very least, confusing - to refer to illicit digging as "looting" which is a "transnational crime," involving a "series of crimes," and on a "more localized level ... [the] theft of cultural objects" (Yates 2016, para. 1, 2, 9), and at the same time, that many who do the actual digging are simply victims in a position of "extreme poverty" (para. 9)? Why are archaeologists comfortable talking about archaeological site looting as "theft," while not all looters are "thieves"? Who are field archaeologists—often working in areas that are not even their own communities-to decide when it is morally acceptable to loot and when it is not? Who are field archaeologists to assess who is "poor enough" to deserve to loot? Who are archaeologists to condone some types of looting to the exclusion of others, without inevitably condoning the trade in illicitly obtained antiquities?

\section{More Than a Matter of Semantics}

As evidenced here, the reticence among some archaeologists to report archaeological site looting when they encounter it is due, at least in part, to their dichotomization of looting into the kind motivated by greed and perpetrated by "criminals" and, in contrast, the kind motivated by desperation and undertaken by "victims." In my view, this distinction is rather useless on two fronts. First, either "type" of looting undermines the preservation of cultural heritage, and a looter's motivation does not mitigate damage done to the archaeological landscape. Either the archaeological record, and its place in cultural heritage, is important enough to protect from looting, or it is not. One cannot have it both ways. It is one thing to mouth "pious platitudes on plunder in [the classroom], or drop brief comments in print or in lectures that it is not nice to buy plundered antiquities" (Muscarella 2009, p. 396), and quite another to speak up after a firsthand encounter with looting in the field. It is not unreasonable for an archaeologist to consider the safety implications of intervening or reporting archaeological site looting beyond her field crew, but there is a certain irony in the inaction of an archaeologist who has

28 The importance of reporting site looting is also a common component of many codes of archaeological ethics. See, for example, the Archaeological Institute of America's Code of Ethics ("members of the AIA should ... inform appropriate authorities of threats to, or plunder of, archaeological sites"). Available online at: https://www.archaeological.org/news/advocacy/130.

See (Sotiriou 2016). 
decided not to do anything about looting because she deems it excusable based on the premise that there is economic value to be gained from it by those who loot out of economic necessity. That is, this justification for inaction-based squarely on the assessment of the potential economic benefit of saleable looted items for those in dire economic straits-does seem to skirt a field of archaeologists' purported allegiance to archaeological preservation and stewardship (Bauer 2007).

Second, whether field archaeologists view looters as criminals or victims, looting is largely criminalized by domestic statute, and this necessarily changes archaeologists' ethico-legal responsibilities when they bear witness to it. An archaeologist who chooses not to report looting-for whatever reason-is essentially an archaeologist who chooses not to report a crime. It matters little whether there exists an affirmative legal duty for archaeologists to report this crime, because it is incumbent upon them to do so simply by virtue of their specialized education, training, expertise, unique position as "eyewitnesses," and professed commitment to the preservation of cultural heritage. ${ }^{34}$ Further, if many archaeologists consider certain looters to be victims, then could non-reporting also be considered an omission to come to a victim's aid? That is, if archaeologists choose to distinguish illicit diggers who are "victims" of exploitation from illicit diggers who are "criminals" doing the exploitation, then by their own reasoning, archaeologists who encounter looting are now witnesses to both crime and victimization. In this sense, an archaeologist's inaction now becomes a matter of both non-reporting of crimes and non-intervention with victims. To soapbox on the criminal culpability of traffickers and collectors, decry the criminal victimization of looters who dig out of desperation and abject poverty, and still choose not to report or intervene in looting is bystander apathy of the ugliest sort.

It is true that rarely is the act of omission in failing to report a crime or come to a victim's aid actually considered a criminal act, and there are few laws in even fewer countries that create duties to report for members of certain professions. The lack of a codified legal duty to report does not obviate the archaeologist's ethical duty to report looting to an external authority. The rationale is the same whether the obligation is expressed or implied: reporting duties in criminal law are intended to protect the public welfare, and by most archaeologists' measure, preservation of the archaeological record is a "public good." As such, archaeological site looting is an offense against the public good which must be reported (Krieger 2014). As self-proclaimed stewards of cultural heritage—of which public education, outreach, and preservation of archaeological resources as public good are part—an archaeologist can reasonably be held to a higher standard of conduct independent of any legally imposed reporting duty simply by virtue of qualifying to practice archaeology. A moral imperative to deal with archaeological site looting is thus created by both the archaeologist's self-professed commitment to preservation as well as her unique position as a potential eyewitness.

How archaeologists, who have subject matter expertise and firsthand experience in the field, choose to frame their talk about looting and looters-both amongst themselves and amongst the public-is hugely influential. As evidenced in this study, for many archaeologists the distinction between "criminal" and "victim" looters is an important one, and this distinction often underpins the course of action they choose to follow when met face-to-face with looting. It follows, then, that if this distinction is important enough to shape an archaeologist's action in the field, then it should be just as important to acknowledge in his rhetoric. The ease with which many archaeologists are able to condemn certain looters, sympathize with others, and nonetheless refer to all of it with such loaded terms as "crime", "theft," "organized crime," "racketeering," "vandalism," "genocide," and "robbery" seems to undermine this. If it suits archaeologists to broadly couch looting in such charged criminological terms-after all, "cultural racketeering" and "cultural genocide" do have a certain sensational ring to them that captures immediate attention-then they must be prepared to take

34 The ethical duty to report is also noted in, for example, the Archaeological Institute of America's Code of Ethics Principle No. 3, "members of the AIA should ... inform appropriate authorities of threats to, or plunder of archaeological sites ... " (AIA Code of Ethics, approved as amended 29 December 1997). 
everything that comes with the semantic territory-e.g., the ethical duty to report crime and the consequences of bystander apathy.

Put simply, if looting is an incident of crime, even if largely perpetrated by victims of economic exploitation (and there is limited if any hard evidence to suggest that most looting that occurs around the world is in fact 'subsistence digging'), then a looted archaeological site is in fact a crime scene, and by their own logic, archaeologists should "suit up" and consider the site forensically (cf. for example, Kinkopf and Beck 2016). It is difficult to take looting seriously as a criminal offense if many archaeologists on the scene choose not to treat it as such. If well over one-quarter of surveyed field archaeologists choose not to report looting beyond their field crews, then this is indicative that at least some looting is considered inconsequential if not justifiable or excusable. Non-reporting archaeologists must then entertain the possibility that their witness passivity in the face of criminalized archaeological site looting may make them enablers:

Lots of archaeologists I know couldn't care less about site looting. I mean, they seem to look at it more as a nuisance than anything. They really need to look at looting as 'crimes' rather than a nuisance. I think because they don't view looting as criminal then they don't really feel obligated to report it. They are facilitating looting by their inaction.

$$
\text { -Archaeologist \#1830, Britain }
$$

Considering the proximity of archaeologists to looting, the possibility of facilitative effects of non-reporting is not unreasonable. If an archaeologist is ethically obliged to avoid any action-or in this case, inaction-that might incentivize looting or facilitate the antiquities trade, ${ }^{35}$ then an archaeologist must honestly consider the possibility that her failure to act could amount to passive enablement. She must also consider that her inaction may have the capacity to produce results no less detrimental than would active encouragement of archaeological site looting. If looting is a crime, it matters not whether a looter is "criminal" or "victim." The damage to the archaeological record is irreversible despite the fundamental incompatibility of criminalized looting (what many archaeologists denounce in public) with victimized looters (what many archaeologists lament in private). ${ }^{36}$ In my view, this is the sort of fence-sitting that an archaeologist does when she does not want to commit to one position or the other.

Much of this fence-sitting is likely due to a lack of standardized professional protocol on what field archaeologists should do when bearing witness to looting. If I encounter looting or looters, whom should I call? What steps should I take? If archaeologists share general values and ethics, then despite jurisdictional incongruencies, surely there are some basic looting reporting strategies applicable to all field settings, too. At minimum, the subject of looting and its intersection with archaeological ethics should play a more formal, central role in both academic classrooms and archaeological organizations' codes of ethics with clearer, more specific directives on reporting site looting or how to handle an encounter with looters. ${ }^{37}$ Further, more public and frank discussion about looting is warranted in that archaeology has largely moved beyond a public outreach model to one of community-oriented archaeology. If communities are ever to play a truly active role in archaeological fieldwork - as opposed to being passive recipients upon whom a perfunctory lecture and cocktail party are bestowed at the end of each dig season-then it is incumbent upon all field archaeologists to deal more directly with the issue of encountering site looting. As experts in their field, it matters what archaeologists do or do not do about looting, and those decisions are no more

\footnotetext{
(Brodie 2008).

On reasons why some archaeologists are precluded from expressing a "closeted sympathy" for diggers, see Matsuda (1998, 2005).

3 For example, the Archaeological Institute of America's Code of Ethics Principle No. 2 is rather vague, stating only that members of the AIA should "refuse to participate in the trade in undocumented antiquities and refrain from activities that enhance the commercial value of such objects" (AIA Code of Ethics, approved as amended, 29 December 1997). In a similar vein, the Society for American Archaeology directs archaeologists to "discourage, and themselves avoid, activities that enhance the commercial value of archaeological objects (SAA Principles of Archaeological Ethics, Principle No. 3).
} 
ethically neutral than they are value-free. As a modest start to any serious consideration of long-term, coordinated anti-plunder strategies, required of field archaeologists is a candid consideration of why so few of them are outspoken about the matter of looting. Damage to the archaeological landscape is not dependent on whether looting is motivated by greed or need; neither is it dependent on an archaeologist's motivations for non-reporting. When an archaeologist is next met with looting in the field, she might do well to consider seriously the implications of her actions or inactions.

Funding: This research received no external funding.

Conflicts of Interest: The authors declare no conflicts of interest.

\section{References}

Aarons, Lisette. 2001. Art theft: An exploratory study of the illegitimate art market in Australia. Australian $\mathcal{E}$ New Zealand Journal of Criminology 34: 17-37.

Aarons, Lisette, Duncan Chappell, and Kenneth Polk. 1998. Art Crime in Australia: A Market Analysis. Paper presented at the Annual Australian and New Zealand Society of Criminology Conference, Gold Coast, Queensland, July 10.

Akhtar, Zia. 2012. Theft in Babylon: Repatriation and International Law. Art, Antiquity E Law 17: 325-46.

Alder, Christine, and Kenneth Polk. 2002. Stopping this awful business: The illicit traffic in antiquities examined as a criminal market. Art, Antiquity, E Law 7: 35-53.

Alder, Christine, and Kenneth Polk. 2005. The illicit traffic in plundered antiquities. In Handbook of Transnational Crime and Justice. Edited by Philip Reichel. Thousand Oaks: Sage Publications.

Alderman, Kim. 2010. The ethics of context: Exploring assumptions in discussions about the looting of archaeological sites. Journal of Art Crime 4: 93.

Alderman, Kimberly L., and Chelsey S. Dahm. 2014. National treasure: A comparative analysis of domestic laws criminalizing illicit excavation and exportation of archaeological objects. Mercer Law Review 65: 431.

Andrews, Edmund. 2003. Global Network Speeds Plunder of Iraqi Antiquities. New York Times, May 28. Available online: https:/ /www.nytimes.com/2003/05/28/world/after-the-war-culture-global-networkspeeds-plunder-of-iraqi-antiquities.html (accessed on 20 April 2018).

Atalay, Sonya. 2012. Community-Based Archaeology. Berkeley: University of California Press.

Balcells Magrans, Marc. 2018. Contemporary Archaeological Looting: A Criminological Analysis of Italian Tomb Robbers. Ph.D. dissertation, City University of New York, New York, NY, USA. Available online: https:/ / academicworks.cuny.edu/gc_etds/2538/ (accessed on 2 April 2018).

Bauer, Alexander A. 2007. New ways of thinking about cultural property: A critical appraisal of the antiquities trade debates. Fordham International Law Journal 31: 690-724.

Bennett, Will. 2003. Professor Calls for Looters to Be Shot. The Telegraph, July 9. Available online: https:/ / www.telegraph.co.uk/news/worldnews/northamerica/usa/1435653/Professor-calls-forlooters-to-be-shot.html (accessed on 20 April 2018).

Bernick, Lauren. 1998. Art and antiquities theft. Transnational Organized Crime 4: 91-116.

Boateng, Francis D. 2012. Public Trust in the Police: Identifying Factors That Shape Trust in the Ghanaian Police (IPES Working Paper Series No. 42). Available online: www.ipes.info/WPS/WPS_No_42.pdf (accessed on 8 April 2018).

Boateng, Francis D. 2016. Crime reporting behavior: Do attitudes toward the police matter? Journal of Interpersonal Violence. [CrossRef]

Bogdanos, Matthew. 2005. Thieves of Baghdad. New York: Bloomsbury USA.

Bohstrom, Philippe. 2017. Diving Robbers Are Looting Underwater Treasures. Haaretz, March 15. Available online: https: / / www.haaretz.com/archaeology/diving-robbers-looting-underwater-treasures-1.5449229 (accessed on 20 April 2018).

Bowman Proulx, Blythe. 2008. Transnational Crimes against Culture: Looting at Archaeological Sites and the "Grey" Market in Antiquities. Journal of Contemporary Criminal Justice 24: 225-42. [CrossRef]

Bowman Proulx, Blythe. 2010. Organized criminal involvement in the illicit antiquities trade. Trends in Organized Crime 14: 1-29. [CrossRef] 
Bowman Proulx, Blythe. 2011. Drugs, arms, and arrowheads: Theft from archaeological sites and the dangers of fieldwork. Journal of Contemporary Criminal Justice 27: 500-22. [CrossRef]

Bowman Proulx, Blythe. 2013. Looting at archaeological sites in "glocal" perspective: Nature, scope, \& frequency of the problem. American Journal of Archaeology 117: 111-25.

Brisman, Avi. 2011. 'Green harms' as art crime, art criticism, as environmental dissent. Journal of Contemporary Criminal Justice 27: 465-99. [CrossRef]

Brodie, Neil. 2002. Introduction. In Illicit Antiquities: The Theft of Culture and the Extinction of Archaeology. Edited by Neil Brodie and Kathryn Walker Tubb. London: Routledge.

Brodie, Neil. 2003. Stolen history: Looting and illicit trade. Museum International 55: 10-22. [CrossRef]

Brodie, Neil. 2006. An archaeologist's view of the trade in unprovenanced antiquities. In Art E Cultural Heritage: Law, Policy, E Practice. Edited by Barbara Hoffman. Cambridge: Cambridge University Press.

Brodie, Neil. 2008. Cultural Heritage and Human Rights: A Critical View. Paper presented at the Roundtable Discussion at the American Anthropological Association 2008 Annual Meeting, San Francisco, CA, USA, November 19-23.

Brodie, Neil. 2011. Congenial bedfellows? The academy and the antiquities trade. Journal of Contemporary Criminal Justice 27: 441-40. [CrossRef]

Brodie, Neil, and Christina Luke. 2006. Conclusion: The social and cultural contexts of collecting. In Archaeology, Cultural Heritage, and the Antiquities Trade. Edited by Neil Brodie, Kersel Morag, Luke Christina and Katheryn Walker Tubb. Gainesville: University Press of Florida, pp. 303-17.

Brodie, Neil, Jennifer Doole, and Colin Renfrew, eds. 2001. Trade in Illicit Antiquities: The Destruction of the World's Archaeological Heritage. Cambridge: McDonald Institute for Archaeological Research.

Brown, Patricia. 2015. Receding Waters in California Expose Artifacts to Plundering. New York Times, December 1. Available online: https:/ /www.nytimes.com/2015/12/02/us/receding-waters-in-californiaexpose-artifacts-to-plunder.html (accessed on 20 April 2018).

Cannon-Brookes, Peter. 1994. Antiquities in the market-place: Placing a price on documentation. Antiquity 68: 349-50. [CrossRef]

Chabiera, Aleksandra. 2011. Stop Heritage Crime. INTERPOL. Available online: https:/ /www.interpol.int/ Media/Files/Crime-areas/Works-of-art/Stop-heritage-crime (accessed on 20 April 2018).

Coggins, Clemency. 1969. Illicit traffic in pre-columbian antiquities. Art Journal 29: 94-98. [CrossRef]

Coggins, Clemency. 1998. United States cultural property legislation: Observations of a combatant. International Journal of Cultural Property 7: 52-68. [CrossRef]

Conklin, John. 1994. Art Crime. Westport: Praeger.

De la Torre, Laura. 2006. Terrorists Raise Cash by Selling Antiquities. Government Security News, February 20, p. 4. Available online: https://savingantiquities.org/wp-content/uploads/2015/02/GSN-safe.pdf (accessed on 15 November 2006).

DeBoer, Warren R. 1999. Metaphors we dig by. Anthropology News 40: 7-8. [CrossRef]

Dietzler, Jessica. 2013. On 'organized crime in the illicit antiquities trade: Moving beyond the definitional debate. Trends in Organized Crime 16: 329-42. [CrossRef] [PubMed]

Durney, Mark, and Blythe Proulx. 2011. Art crime: A brief introduction. Crime, Law and Social Change 56: 115-32. [CrossRef]

Efrat, Asif. 2009. Protecting against Plunder: The United States and the International Efforts against Looting of Antiquities. Cornell Faculty Working Papers Series. Available online: https:/ / scholarship.law.cornell.edu/ cgi / viewcontent.cgi?article=1049\&context=clsops_papers (accessed on 18 June 2018).

Elia, Ricardo J. 1993. A seductive and troubling work. Archaeology 46: 64-69.

Fagan, Brian. 1985. In the Beginning: An Introduction to Archaeology, 5th ed. Boston: Little, Brown, \& Co.

Felch, Jason, and Ralph Frammolino. 2011. Chasing Aphrodite: The Hunt for Looted Antiquities at the Getty Museum. New York: Harcourt Mifflin.

Fincham, Derek. 2014. Two Ways of Policing Cultural Heritage. Paper presented at the International Conference on "Protecting Cultural Heritage as a Common Good of Humanity: A Challenge for Criminal Justice", Courmayeur, Italy, December 13-15. Edited by Stefano Manacorda and Arianna Visconti. pp. 85-92.

Flannery, Kent V., and Joyce Marcus. 1998. Cognitive archaeology. In Reader in Archaeological Theory: Post-Processual and Cognitive Approaches. Edited by David S. Whitley. London: Routledge, pp. 35-48. 
Gill, David, and Christopher Chippindale. 1993. Material and intellectual consequences of esteem for Cycladic figures. American Journal of Archaeology 97: 602-73. [CrossRef]

Glazer, Sarah. 2017. Stolen antiquities. CQ Researcher 27: 945-68.

Goudriaan, Heike, Karin Wittebrood, and Paul Nieuwbeerta. 2006. Neighborhood characteristics and reporting crime: Effects of social cohesion, confidence in police effectiveness and socio-economic disadvantage. British Journal of Criminology 46: 719-42. [CrossRef]

Greenberg, Max. 2016. Looters, Vandals Threaten Some of America's Great Archaeological Sites in Bears Ears. Wilderness Society, August 24. Available online: https://wilderness.org/blog/looters-vandals-threatensome-americas-great-archaeological-sites-bears-ears (accessed on 20 April 2018).

Halperin, Julia. 2017. The Vast Majority of Antiquities Sold Online Are Probably Looted or Fake, a New Report Says. Artnet News, November 1. Available online: https://news.artnet.com/art-world/antiquities-soldonline-fake-1135832 (accessed on 4 April 2018).

Hamblin, Dora Jane. 1970. Pots and Robbers. New York: Simon \& Schuster.

Harari, Orly. 2017. Antiquities Thieves Caught Red-Handed. ArutzSheva, March 15. Available online: https: / /www.israelnationalnews.com/News/News.aspx/226744 (accessed on 20 April 2018).

Hardy, Sam. 2015. Virtues impracticable and extremely difficult: The human rights of subsistence diggers. In Ethics and the Archaeology of Violence. Edited by Alfredo Gonzalez-Ruiz. New York: Springer, pp. 229-39.

Harkin, James. 2016. The Race to Save Syria's Archaeological Treasures. Smithsonian Magazine, March. Available online: https: / www.smithsonianmag.com/history / race-save-syrias-archaeological-treasures-180958097/ (accessed on 20 April 2018).

Hollowell, Julie. 2006a. Moral arguments on subsistence digging. In The Ethics of Archaeology: Philosophical Perspectives on the Practice of Archaeology. Edited by Christopher Scarre and Geoffrey Scarre. Cambridge: Cambridge University Press, pp. 69-93.

Hollowell, Julie. 2006b. St lawrence island's legal market in archaeological goods. In Archaeology, Cultural Heritage, and the Antiquities Trade. Edited by Neil Brodie, Morag M. Kersel, Christina Luke and Kathryn Walker Tubb. Gainesville: University Press of Florida.

Holtorf, Cornelius. 2005. From Stonehenge to Las Vegas: Archaeology as Popular Culture. Lanham: Rowman \& Littlefield Publishing.

Howard, Russell D., Jonathan Prohov, and Marc D. Elliott. 2016. IS and Cultural Genocide: Antiquities Trafficking in the Terrorist State. JSOU Report, November. Available online: http:/ / unesdoc.unesco.org/images/0012/ 001232/123243e.pdf (accessed on 20 April 2018).

INTERPOL. 2007. Stolen Works of Art: Frequently Asked Questions. Available online: http:/ /www.interpol.int/ Public/WorkOfArt/woafaq.asp (accessed on 20 December 2007).

Kääriäinen, Juha, and Reino Sirén. 2011. Trust in the Police, Generalized Trust and Reporting Crime. European Journal of Criminology 8: 65-81. [CrossRef]

Kantchev, Georgi. 2017. Buyer Beware: Looted Antiquities Flood Online Sites Like Amazon, Facebook. Wall Street Journal, November 1. Available online: https:/ / www.wsj.com/amp/articles/the-online-bazaar-for-lootedantiquities-1509466087 (accessed on 4 April 2018).

Kennedy, Maev. 2003. Kill Looters, Urges Archaeologist. The Guardian, July 9. Available online: https:/ /www. theguardian.com/uk/2003/jul/09/iraq.internationaleducationnews (accessed on 20 April 2018).

Kinkopf, Katherine M., and Jess Beck. 2016. Bioarchaeological approaches to looting: A case study from Sudan. Journal of Archaeological Science: Reports 10: 263-71. [CrossRef]

Krieger, William H. 2014. Marketing archaeology. Ethical Theory \& Moral Practice 17: 923-39.

Lane, David C., David G. Bromley, Robert D. Hicks, and John S. Mahoney. 2008. Time crime: The transnational organization of art and antiquities theft. Journal of Contemporary Criminal Justice 24: 243-62. [CrossRef]

Lehr, Deborah. 2013. Cultural Racketeering and Why It Matters: Robbing the World of History. Huffington Post, October 1. Available online: https:/ / www.huffingtonpost.com/deborah-lehr/cultural-racketeering-and_b_ 4025586.html (accessed on 20 April 2018).

Little, Barbara J. 2007. Archaeology and Civic Engagement. In Archaeology as a Tool of Civic Engagement. Edited by Barbara J. Little and Paul A. Shackel. Landham: Altamira Press, pp. 1-22.

Lovell, Jeremy. 2003. Donny George Says Museum Looters Should Be Shot. Reuters, July 9. Available online: http:/ / zindamagazine.com/html/archives/2003/7.7.03/index.php (accessed on 20 April 2018). 
Lynott, Mark J. 1997. Ethical principles and archaeological practice: Development of an ethics policy. American Antiquity 62: 589-99. [CrossRef]

Mackenzie, Simon R. M. 2005. Going, Going, Gone: Regulating the Market in Illicit Antiquities. Leicester: Institute of Art and Law.

Mackenzie, Simon, and Tess Davis. 2014. Temple looting in Cambodia: Anatomy of a statute trafficking network. British Journal of Criminology 54: 722-40. [CrossRef]

Marenin, Otwin. 1997. Victimization surveys and the accuracy and reliability of official crime data in developing countries. Journal of Criminal Justice 25: 463-75. [CrossRef]

Massy, Laurence. 2001. Le Vol D'OeuvresD'Art: UneCriminalitéMéconnue. Bruxelles: Bruylant.

Matsuda, David. 1998. The ethics of archaeology, subsistence digging, and artifact looting in Latin America. International Journal of Cultural Property 7: 87-97. [CrossRef]

Matsuda, David. 2005. Subsistence Diggers. In Who Owns the Past? Cultural Policy, Cultural Property, and the Law. Edited by Karen Fitz Gibbons. New Brunswick: Rutgers University Press, pp. 225-65.

Moser, Stephanie. 2007. On disciplinary culture: Archaeology as fieldwork and its gendered associations. Journal of Archaeological Method \& Theory 14: 235-63.

Mueller, Tom. 2016. How Tomb Raiders Are Stealing Our History. National Geographic, June 5. Available online: https:/ / www.nationalgeographic.com/magazine/2016/06/looting-ancient-blood-antiquities/ (accessed on 10 April 2018).

Muscarella, Oscar White. 2000. The Lie Became Great: The Forgery of Near Eastern Cultures. Boston: Brill Academic Publishers.

Muscarella, Oscar White. 2009. The Fifth Column Within the Archaeological Realm: The Great Divide. In Studies in Honour of AltanÇilingiroğlu: A Life Dedicated to Urartu on the Shores of the Review Articles 463 Upper Sea. Edited by Derin Zafer, Haluk Sağlamtimur and Eşref Abay. Istanbul: Arkeolojive Sanat Yayınları, pp. 395-406.

Nadeau, Barbie Latza. 2016. Italian Mob Trades Weapons for Looted Art Frim ISIS in Libya. The Daily Beast, October 8. Available online: https:/ / www.thedailybeast.com/italian-mob-trades-weapons-for-looted-artfrom-isis-in-libya (accessed on 20 April 2018).

Nicholas, George P., and Alison Wylie. 2009. Archaeological finds: Legacies of appropriation, modes of response. In The Ethics of Cultural Appropriation. Edited by James O. Young and Conrad G. Brunk. Malden: Blackwell, pp. 11-54.

Nicholas, George P., John R. Welch, and Eldon C. Yellowhorn. 2008. Collaborative Encounters. In Collaboration in Archaeological Practice: Engaging Descendant Communities. Edited by Chip Colwell-Chanthaphonh and Thomas John Ferguson. Lanham: AltaMira Press, pp. 273-98.

Perticarari, Luigi, and Anna Maria Giuntani. 1986. I segreti di un tombarolo. Milan: Rusconi.

Politis, Konstantinos. 1994. Biblical Zoar: The looting of an ancient site. Minerva 5: 12-15.

Prescott, Christopher, and Atle Omland. 2003. The Schøyen Collection in Norway. Culture without Context 13: 8-11.

Renfrew, Colin. 2002. Loot, Legitimacy, E Ownership. London: Duckworth.

Rosenbaum, Dennis P., Amie M. Schuck, Sandra K. Costello, Darnell F. Hawkins, and Marianne K. Ring. 2005. Attitudes toward the police: The effects of direct and vicarious experience. Police Quarterly 8: $343-65$. [CrossRef]

Sadeghi, H. M. M. 2014. Cultural heritage crime in the Islamic penal code of Iran. Paper presented at the International Conference on "Protecting Cultural Heritage as a Common Good of Humanity: A Challenge for Criminal Justice", Courmayeur, Italy, December 13-15.

Siehr, Kurt. 2008. Rogues, robbers, and researchers: Robbery of antiquities and archaeology under the present legal situation. International Journal of Cultural Property 15: 407-8. [CrossRef]

Smith-Meyer, Bjarke. 2017. Commission Targets Terrorists Trafficking in Antiquities. Politico, July 13. Available online: https:/ / www.politico.eu/article/commission-targets-terrorists-trafficking-in-antiques/ (accessed on 4 April 2018).

Sotiriou, Konstantinos-Orfeas. 2016. Why archaeological sites are crime scenes. OSCE Security Community 2: 16-17. Steinbuch, Yaron. 2017. ISIS Digs Underground Tunnerls to Plunder Ancient Treasures. New York Post, March 7. Available online: https:/ / nypost.com/2017/03/07/isis-digs-underground-tunnels-to-plunder-ancienttreasures/ (accessed on 20 April 2018).

Stille, Alexander. 1999. Head found on Fifth Avenue: Investigators finally think they know who's been taking the ancient treasures of Sicily. The New Yorker, LXXV 12: 58-69. 
Summers, Roger. 1950. Armchair archaeology. South African Archaeological Bulletin 5: 101-4. [CrossRef]

Sunshine, Jason, and Tom R. Tyler. 2003. The role of procedural justice and legitimacy in shaping public support for policing. Law \& Society Review 37: 513-48.

Taylor, Walter Willard. 1948. A Study of Archaeology. Washington: American Association of Anthropology.

Thompson, Erin L. 2015. But We Didn't Steal It: Collectors' Justifications for Purchasing Looted Antiquities. Journal of Art Crime 13: 59-67.

Tijhuis, Antonius Johannes Gerhardus. 2006. Transnational Crime and the Interface between Legal and Illegal Factors: The Case of the Illicit Art and Antiquities Trade. Nijmegen: Wolf Legal Publishers.

UNESCO. 2001. Address Given at the Closing Session of ISESCO's International Symposium on “Dialogue among Civilizations in a Changing World. p. 3. Available online: http:/ / unesdoc.unesco.org/images/0019/001914/ 191484e.pdf (accessed on 20 April 2018).

Wylie, Alison. 1996. Ethical Dilemmas in Archaeological Practice: Looting, Repatriation, Stewardship, and the (Trans)formation of Disciplinary Identity. Perspectives on Science 4: 154-94.

Yahya, Adel. 2010. Looting and "salvaging" the heritage of Palestine. Present Pasts 2: 96-100. [CrossRef]

Yates, Donna. 2016. The Global Traffic in Looted Cultural Objects. In The Oxford Encyclopedia of Crime, Media, and Popular Culture. Edited by Nicole Hahn Rafter and Michelle Brown. Oxford: Oxford University Press, chp. 27. Available online: http://criminology.oxfordre.com/view/10.1093/acrefore/9780190264079.001. 0001/acrefore-9780190264079-e-124 (accessed on 20 April 2018).

(C) 2018 by the author. Licensee MDPI, Basel, Switzerland. This article is an open access article distributed under the terms and conditions of the Creative Commons Attribution (CC BY) license (http:/ / creativecommons.org/licenses/by/4.0/). 